\title{
Thrombopoietin receptor agonists for treatment of poor graft function after allogeneic hematopoietic stem cell transplantation in adults
}

Tatiana A. Rudakova, Alexander D. Kulagin, Ivan S. Moiseev, Tatyana A. Bykova, Sergey N. Bondarenko, Maria V. Barabanshikova, Anastasia V. Beinarovich, Anna A. Osipova, Varvara N. Ovechkina, Alexander L. Alyanskiy, Elena I. Darskaya, Elena V. Morozova, Boris V. Afanasyev

Raisa Gorbacheva Memorial Research Institute of Pediatric Oncology, Hematology and Transplantation, Chair of Hematology, Transfusiology and Transplantology, Pavlov First Saint Petersburg State Medical University, St. Petersburg, Russia

Dr. Tatiana A. Rudakova, Raisa Gorbacheva Memorial E-mail: t_a_rudakova@mail.ru

Research Institute of Pediatric Oncology, Hematology and

Transplantation, Pavlov First Saint Petersburg State Medical

University, L. Tolstoy St 6-8, 197022, St. Petersburg, Russia

Citation: Rudakova TA, Kulagin AD, Moiseev IS et al. Thrombopoietin receptor agonists for treatment of poor graft function after allogeneic hematopoietic stem cell transplantation in adults. Cell Ther Transplant 2019; 8(2): 38-44.

\section{Summary}

Posttransplant cytopenias due to poor graft function (PGF) are a severe complication of allogeneic transplantation of hematopoietic stem cells (allo-HSCT). Conventional therapeutic options for poor graft function are limited to infusions of CD34-selected cells. However, having shown encouraging results in idiopathic thrombocytopenia and aplastic anemia, thrombopoietin receptor agonists (TPO-RA) romiplostim and eltrombopag might be a possible alternative treatment strategy for PGF after alloHSCT. Current study aims to summarize single-center experience of TPO-RA for treatment of posttransplant cytopenias including PGF after allo-HSCT.

A total of 31 patients (15 males, 16 females) with median age of 22 years (18-57) received therapy with TPO agonists for posttransplant thrombocytopenia $<20 \times 10^{9} / 1$ $(\mathrm{n}=7)$ and PGF $(\mathrm{n}=24)$. Romiplostim $(\mathrm{n}=17)$ with the median dose $5 \mathrm{mkg} / \mathrm{kg}$ weekly (3-5) or eltrombopag $(\mathrm{n}=14)$ with the median dose $50 \mathrm{mg} /$ day $(50-150)$ were used. Criteria for severe poor graft function (sPGF) were the following: cytopenia in two or more myeloid lineages (platelets $<20 \times 10^{9} / 1$, absolute neutrophil count (ANC) $<0.5 \times 10^{9} / 1$, hemoglobin $<70 \mathrm{~g} / \mathrm{l}$ ) any time after documented engraftment, full or stable mixed donor chimerism $>90 \%$ without signs of relapse of underlying disease. Overall response included complete response (CR) (platelets $\geq 100 \times 10^{9} / \mathrm{l}$, ANC $\geq 1.5 \times 10^{9} / \mathrm{l}$, hemoglobin $\geq 100 \mathrm{~g} / \mathrm{l}$ ) and partial response (PR) (platelets $>20 \times 10^{9} / \mathrm{l}$, ANC $\geq 0.5 \times 10^{9} / \mathrm{l}$, hemoglobin $\left.>70 \mathrm{~g} / \mathrm{l}\right)$.
Median time from diagnosis of sPGF to the start of TPO-RA therapy was 14 days (0-119), median length of TPO-RA therapy was 3 weeks (1-43). TPO-RA was well tolerated, with no signs of II-IV grade toxicity. In a total of 8 cases (28\%) TPO-RA were used in combination with rituximab $(n=4)$, rituximab and donor lymphocyte infusions (DLI) $(n=3)$, as well as CD34-cell infusions $(n=1)$. A total of $14(48 \%)$ patients achieved response (CR: $n=4$, 14\%; PR: $n=10,34 \%)$. Combination therapy showed no advantage in response rate compared to TPO-RA alone. Median increase of ANC in responders was $3.4 \times 10^{9} / 1$ (0.8-6.0), platelets $-48 \times 10^{9} / 1$ (21-205). A total of $15 \mathrm{pa}-$ tients ( 3 responders, 12 non-responders) died of infection $(n=10)$, relapse $(n=2)$ and acute graft-versus-host disease (aGVHD) III-IV grade $(n=3)$. One-year overall survival (OS) from the therapy start was 60\% (95\% CI, 40-76), with a significant difference between responders and non-responders: $79 \%$ (95\% CI, 47-93) vs 39\% (95\% CI, 14-63) $(\mathrm{p}=0.01)$.

Our study showed a promising efficacy and safety of TPO-RA in patients with sPGF after allo-HSCT. Multicenter prospective studies are needed to establish optimal dose and duration of the drug administration, as well as the criteria for discontinuation of these drugs.

\section{Keywords}

Allo-HSCT, poor graft function, thrombopoietin receptor agonists. 


\section{Introduction}

Allogeneic hematopoietic stem cell transplantation (alloHSCT) is one of the most rapidly developing fields of medicine $[1,2,3,4]$. Improvement of allo-HSCT technology allowed focusing on the new challenges. One of those issues is poor graft function (PGF). The incidence of PGF depends on many factors, e.g., diagnosis of the underlying disease, type of allo-HSCT, ABO-compatibility, viral reactivation, and varies between $5 \%$ and $20 \%$, according to the most publications [5-8]. However, given the multifactorial nature of PGF, as well as frequent inability to perform etiological therapy, the treatment options are limited and poor standardized [9, $10]$.

Thrombopoietin is one of the main physiological regulators of platelet production and was initially considered as a linear growth factor for megakaryocytes. However, a number of studies have shown that $\mathrm{Mpl}$ expression is detected in 70\% of hematopoietic stem cells. Thus, thrombopoietin alone or in combination with other cytokines stimulates the proliferation of early hematopoietic precursors [11, 12]. These data allowed the use of TPO-RA for the treatment of both idiopathic thrombocytopenic purpura and aplastic anemia with promising results [13-15]. The safety of using TPORA for malignant diseases has been questioned, however, it was analyzed in a large cohort study which showed TPORA therapy did not affect relapse of acute myeloid leukemia [16-18]. Recently, a number of studies have been conducted in order to expand the obtained experience to the setting of posttransplant cytopenias. TPO-RA has shown a positive effect in posttransplant thrombocytopenia, and there are some data suggesting functional improvement of other hematopoietic lineages.

Current study aims to summarize single-center experience of TPO-RA for treatment of posttransplant cytopenias, including PGF, following allo-HSCT. In this report, we present data on the efficacy of TPO-RA in a large single-center adult cohort with PGF.

\section{Patients and methods}

We have performed clinical analysis of thirty-one adult patients at the median age of $22(18-56)$ years old who received TPO-RA for treatment of cytopenia after allo-HSCT in the R. Gorbacheva Memorial Research Institute of Children Oncology, Hematology and Transplantation at the First St. Petersburg State I. Pavlov Medical University.

The inclusion criteria were as follows: 1) thrombocytopenia $<20 \times 10^{9} / 1$ with or without cytopenias in other hematopoietic lines; 2) complete of stable mixed donor chimerism $\geq 90 \%$; 3) no signs of relapse of underlying disease, or hematopoietic graft rejection. The spectrum of disorders in which allo-HSCT was indicated is shown in Table 1.

Conditioning regimen considered to be myeloablative (MAC) $(\mathrm{n}=11.38 \%)$ at the dosage of oral busulfan $\geq 10 \mathrm{mg} / \mathrm{kg}$. Dose of busulfan in reduced intensity regimes (RIC) was 10 $\mathrm{mg} / \mathrm{kg}(\mathrm{n}=18,62 \%)$. Depending on the severity of cytopenia, three groups were selected by the following criteria: 1) mild
Table 1. Characteristics of the patients

\begin{tabular}{|c|c|}
\hline Parameter & Number of cases \\
\hline Total number & 31 \\
\hline Age (median), years & $22(18-57)$ \\
\hline $\begin{array}{l}\text { Gender } \\
\text { Male } \\
\text { Female }\end{array}$ & $\begin{array}{l}15 \\
16\end{array}$ \\
\hline $\begin{array}{l}\text { Diagnosis } \\
\text { AML } \\
\text { ALL } \\
\text { MDS } \\
\text { MDS/MPN } \\
\text { CML } \\
\text { NHL } \\
\text { SAA }\end{array}$ & $\begin{array}{l}11 \\
7 \\
3 \\
4 \\
1 \\
1 \\
4\end{array}$ \\
\hline $\begin{array}{l}\text { Donor type } \\
\text { Related HLA-matched } \\
\text { Unrelated } \\
\text { Haploidentical }\end{array}$ & $\begin{array}{l}5 \\
17 \\
9\end{array}$ \\
\hline $\begin{array}{l}\text { Conditioning regimen } \\
\text { MAC } \\
\text { RIC }\end{array}$ & $\begin{array}{l}11 \\
20\end{array}$ \\
\hline $\begin{array}{l}\text { GVHD prevention } \\
\text { ATG+CsA/tacrolimus } \\
\text { ptCy+CsA/tacrolimus } \\
\text { ptCy+other } \\
\text { Other }\end{array}$ & $\begin{array}{l}9 \\
11 \\
8 \\
3\end{array}$ \\
\hline $\begin{array}{l}\text { aGVHD III-IV } \\
\text { Yes } \\
\text { No }\end{array}$ & $\begin{array}{l}13 \\
18\end{array}$ \\
\hline $\begin{array}{l}\text { Number of cytopenic lines } \\
\text { Isolated thrombocytopenia } \\
\text { Bilineage } \\
\text { Trilineage }\end{array}$ & $\begin{array}{l}7 \\
11 \\
13\end{array}$ \\
\hline $\begin{array}{l}\text { TP0-RA drugs } \\
\text { Romiplostim 3-8 mg/kg } \\
\text { Eltrombopag 50-150 mg/day }\end{array}$ & $\begin{array}{l}17 \\
14\end{array}$ \\
\hline $\begin{array}{l}\text { Therapeutic combinations } \\
\text { Romiplostim } \\
\text { Eltrombopag } \\
\text { TP0-RA and rituximab } \\
\text { TPO-RA and DLI } \\
\text { TP0-RA and "boost" }\end{array}$ & $\begin{array}{l}14 \\
8 \\
5 \\
3 \\
1\end{array}$ \\
\hline
\end{tabular}

ALL, acute lymphoblastic leukemia; $A M L$, acute myeloid leukemia; CML, chronic myeloid leukemia; GVHD, graftversus-host disease; MDS, myelodisplastic syndrome; MDS/ MPN, myelodysplastic/myeloproliferative neoplasm; NHL, non-Hodgkin's lymphoma; SAA, severe aplastic anemia; TPO-RA, thrombopoietin receptor agonists; ATG, antithymocyte globulin; DLI, donor lymphocyte infusion. 
PGF: ANC 1.0-1.5 $\times 10^{9} / 1$; platelets $50-100 \times 10^{9} / 1$; hemoglobin $>100 \mathrm{~g} / \mathrm{l}$; 2) moderate PGF: ANC $0.5-1.0 \times 10^{9} / \mathrm{l}$; platelets 20-50×109/1; hemoglobin 70-100 g/l, 3) severe PGF: ANC $<0.5 \times 10^{9} / 1$; platelets $<20 \times 10^{9} / 1$; hemoglobin $<70 \mathrm{~g} /$ l.

The response to TPO-RA therapy was assessed according to the hemogram dynamics: complete response: ANC $\geq 1.0 \times$ $10^{9} / \mathrm{l}$, platelets $\geq 50 \times 10^{9} / \mathrm{l}$, hemoglobin $\geq 80 \mathrm{~g} / \mathrm{l}$; partial response: ANC $\geq 0.5 \times 10^{9} / 1$, platelets $\geq 20 \times 10^{9} / 1$, hemoglobin $\geq 70 \mathrm{~g} / \mathrm{l}$; no response: ANC $<0.5 \times 10^{9} / 1$, platelets $<20 \times 10^{9} / 1$, hemoglobin $<70 \mathrm{~g} / \mathrm{l}$. Clinical outcomes of PGF were considered as: 1) any response to therapy, 3 ) recurrence of a malignant disease, 3 ) death.

The TPO-RA therapy consisted of romiplostim (Nplate ${ }^{\varpi}$, Amgen) with a median dose of $5 \mathrm{mcg} / \mathrm{kg} /$ week (3-5) or eltrombopag (Revolade ${ }^{\varpi}$, Novartis), with a median dose of 50 (50-150) mg/day.

\section{Statistical analysis}

Descriptive tables were analyzed for patient-related factors, donor and transplantation. Fisher's exact test and Pearson's Chi-square were used to compare binary data. The cumulative response rate was calculated taking into account competing risks (death, relapse). Overall survival (OS) was estimated using the Kaplan-Meier method over the time from administration of TPO agonists to the date of the last contact, or the date of death. The log-rank test was used to evaluate statistical differences between curves. Statistical analysis was performed using SPSS Statistics v.17 software, EZR free statistical environment, version 2.15.2 ( $\mathrm{R}$ Foundation for Statistical Computing, Vienna, Austria).

\section{Results}

This data analysis included 31 patients treated with TPO-RA for PGF after the first or second allo-HSCT. The myeloid engraftment was documented in all cases at the median of 21 (11-48) days. Thrombocytopenia was the indication for the therapy in 7 cases, 10 and 13 patients received TPO-RA for bi- and trilineage cytopenias, respectively. Characteristics of patients and transplants are shown in Table 1.

Malignant diseases prevailed in the diagnosis landscape: $87 \%$ versus $13 \%$, with a significant proportion in the group fell on acute leukemia (55\%) and myeloproliferative diseases (26\%). The majority of patients $(n=17,55 \%)$ were transplanted from unrelated HLA-matched donors. However, the number of allo-HSCT from haploidentical donors was also significant in this cohort $(n=9,29 \%)$. Bone marrow (BM) and peripheral blood stem cells (PBSC) were used as a source of graft in $41 \%$ and $48 \%$ of cases, respectively, whereas a combination of BM and PBSC was applied in $11 \%$ cases.

Majority of the patients were transplanted after RIC: $65 \%$ versus 35\% treated with MAC regimens. GVHD prophylaxis depended on the type of donor and source of the graft. GVHD prophylaxis for all cases of haploidentical HSCTs except of one ( $n=8,26 \%)$ consisted of posttransplant cyclophosphamide (ptCy) in combination with cyclosporine A, or tacrolimus and/or other immunosuppressants (mycophenolate mofetil or sirolimus). For HLA-matched HSCTs,
ptCy, ATG in combination with CsA and methotrexate, and a combination of tacrolimus and mycophenolate mofetil was used in 2 cases, 1 case, and 1 case, respectively. Of the 17 unrelated HLA-matched HSCTs, ATG and ptCy were used in 7 and 10 cases, respectively. Thus, GVHD prophylaxis with ptCy was predominant in the analyzed group $(61 \%, n=19)$. Allo-HSCT with a major AB0-incompatibility took place in $25 \%(n=7)$ cases. Most patients $(81 \%, n=25)$ suffered viral reactivation (mainly cytomegalovirus) and received ganciclovir or valganciclovir at the doses of $5-10 \mathrm{mg} / \mathrm{kg} / \mathrm{day}$, or $450-900 \mathrm{mg} /$ day, respectively. A total of $61 \%(\mathrm{n}=19)$ of the patients had signs of acute infection at the time of starting TPO-RA therapy. The proportion of cases of acute GVHD grade III-IV was also significant (42\%).

The median time from allo-HSCT to PGF was 54 days (18 to $664)$, with prevalence of early PGF ( $n=20,65 \%)$, compared to late PGF $(n=11,35 \%)$. Severe PGF was the most frequent indication for therapy $(\mathrm{n}=24,77 \%)$ vs posttransplant thrombocytopenia $(n=7,23 \%)$.

The median duration of PGF was 59 days (5-426). The median time from the diagnosis of PGF to the start of therapy with TPO-RA was 15 days (0-119). The median duration of the treatment was 3 (1-48) weeks. The median cumulative doses of romiplostim and eltrombopag were 15 (5-70) mg and 2100 (700-50400) mg, respectively.

TPO-RA drugs were well tolerated, with no detectable toxicity of grade 3-4. One case of hepatotoxicity grade 2 was documented with eltrombopag but didn't require withdrawal of the drug.

TPO-RA were used in combination with other therapies in $26 \%$ of cases: rituximab in 5 cases, rituximab and infusion of donor lymphocytes in 3 cases, and a booster dose of CD34+ cells from the same donor was applied in one case.

A total of 16 (52\%) patients developed response to the TPORA. Complete response was documented in 4 cases (13\%), while 12 patients (39\%) showed partial response. The median of increase in ANC in responders was $1.7 \times 10^{9} / 1(0.1-5.6)$, in platelet count $-20 \times 10^{9} / 1(2-205)$. The median cumulative dose of romiplostim in responders was $30 \mathrm{mg} / \mathrm{kg}$ (3.5-73), for eltrombopag it was $4900 \mathrm{mg}$ (2100-50400). The median time of response for romiplostim and eltrombopag was 63 days (5-181) and 103 days (52-426), respectively. Combination therapy had no benefits in the response rate compared to monotherapy with TPO-RA. Overall response was similar for both medications. Our analysis showed no influence of infections (including viral), or acute GVHD grade 3-4 on the cumulative response to the TPO-RA therapy.

Twelve of 16 responders were alive: 7 patients with time of response under median values and 5 patients with time to response exceeding median levels.

A total of 18 patients died. Infectious complications were the main cause of death in these cases $(n=11)$, wherein 8 cases were classified as non-responders, and 3 patients showed longer time to response which exceeded median values. The disease relapse caused death in 4 cases, while aGVHD was associated with lethal outcome in 3 cases. 
One-year OS from the start of therapy with TPO-RA was $60 \%$ (95\% CI, 40-76). It was significantly different for responders and non-responders: 78\% (95\% CI, 47-93) versus $33 \%(95 \%$ CI, 12-56) $(\mathrm{p}=0.004)$, as seen from Fig. 1 .

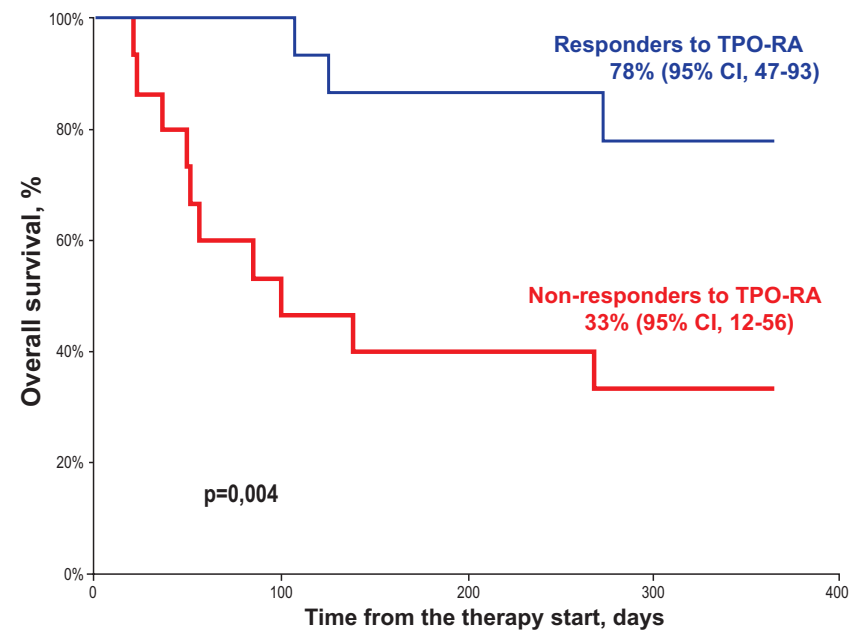

Figure 1. One-year overall survival (OS) curves for responders to TPO-RA drugs, and non-responding patients. Abscissa, time from start of the therapy, days; ordinate $0 S$ rates, \% of total

\section{Discussion}

Allogeneic hematopoietic stem cell transplantation is an effective method for treatment of a wide range of malignant and non-malignant diseases of the blood system. With improving the HSCT technology, most transplanted patients achieve engraftment, but the so-called "poor graft function", i.e., posttransplant cytopenia of various origin with preservation of donor chimerism still remains a challenge. Poor graft function is one of factors significantly worsening the outcome of allo-HSCT [5].

The impairment of hematopoietic stem cell (HSC) compartments after HSCT has been demonstrated by reduced numbers of hematopoietic progenitors under the in vitro culture conditions [19]. The graft functioning might be influenced by the underlying disease, donor and recipient HLA compatibility, the dose of transplanted CD34+ cells, as well as by accompanying complications (GVHD, infections, including viral activation). However, most of the cases remain idiopathic $[20,21,22]$. Most likely, a combination of these factors creates an immune-active environment that hampers the normal development and functioning of transplanted HSCs [23, 24, 25]. Moreover, several post-HSCT conditions (e.g., myelotoxic drugs, inflammatory events, and infections) provide well-established mechanisms impairing hematopoiesis.

TPO-RA drugs, in the context of PGF therapy, may present a promising option, especially, concerning eltrombopag. There are several mechanisms by which eltrombopag may provide effect in the bone marrow failure syndromes. Eltrombopag works as a trigger for HSCs and promotes active proliferation of HSCs after HSCT. Also eltrombopag has an immunomodulatory effect on the T-regulatory cell function [26]. Furthermore, abolition of inhibitory effect produced by interferon- $\gamma$ upon HSCs may be another potential mechanism of eltrombopag action which has been recently explained. Eltrombopag, by its binding directly to c-MPL, activates its intracellular signal transduction pathway, irrespectively of interferon- $\gamma$ presence [27].

Since it is impossible to separate the only etiological factor, the choice of a single approach to the therapy of PGF is complicated. However, given the data on the efficacy of TPO agonists in various bone marrow failure syndromes and other diseases associated with cytopenia, and the safety of their use in malignant diseases, as well as its ability to overcome the immune mechanisms of suppressing hematopoiesis, TPORA seem to be good candidates for management of PGF. Recently, the several groups published the experience of TPORA administration in post-transplant setting [28, 29, 30]. Nevertheless, the precise analysis of efficiency of this therapy is complicated, due to small number of patients and different inclusion criteria in these studies.

We analyzed the results of the use of TPO-RA in our BMT center. The special feature of our cohort was the predominance of patients with severe trilineage cytopenia, as well as high proportion of patients with severe acute GVHD. Our experience showed the safety of TPO-RA: there was only one case of hepatotoxicity of grade 1 , which did not require discontinuation of the drug. Neither the drug used, nor the duration of therapy, nor the cumulative dose of each agent didn't influence overall response in our study. However, there are reports that the cumulative dose for romiplostim plays a role for the overall response to therapy [31].

In our study, there was no statistically significant correlations between the overall response rates to TPO-RA, and clinical complications associated with PGF (sepsis, aGVHD, viral infections), thus being in accordance with results from other centers. However, there is some evidence that a better response could be obtained in the absence of active GVHD [32].

Facing a problem of prolonged cytopenia in the posttransplant period, only booster CD34-cell infusions are considered more or less standardized therapy. TPO-RA used as monotherapy, or in combination with other methods, seem to be quite effective for PGF after allo-HSCT, regardless of its etiology.

\section{Conclusion}

TPO-RA showed promising efficacy and low toxicity in adult patients with PGF after allo-HSCT. Considering multifactorial origin of PGF, TPO-RA might be a reasonable approach that could be applied early and irrespectively of PGF cause. However, the optimal dose and duration of the administration, as well as the criteria for discontinuation of these drugs remain uncertain. Multicenter prospective studies are needed to resolve these problems.

\section{Conflict of interest}

The authors report no conflicts of interest. 


\section{References}

1. Duarte RF, Labopin M, Bader P, Basak GW, Bonini Ch, Chabannon Ch, Corbacioglu S, Dreger P, Dufour C, Andrew R. Gennery AR, Kuball J, Lankester AC, Lanza F, Montoto S, Nagler A, Peffault de Latour R, Snowden JA, Styczynski J, Yakoub-Agha I, Kröger N, Mohty M,for the European Society for Blood and Marrow Transplantation (EBMT). Indications for haematopoietic stem cell transplantation for haematological diseases, solid tumours and immune disorders: current practice in Europe, 2019. Bone Marrow Transplant. 2019 https://doi.org/10.1038/s41409-019-0516-2.

2. Majhail NS, Farnia SH, Carpenter PA, Champlin RE, Crawford S, Marks DI, Omel JL, Orchard PJ, Palmer J, Saber W, Savani BN, Veys PA, Bredeson ChN, Giralt SA, LeMaistre ChF. Indications for autologous and allogeneic hematopoietic cell transplantation: Guidelines from the American Society for Blood and Marrow Transplantation. Biol Blood Marrow Transplant. 2015; 21(11): 1863-1869.

3. Savchenko VG, Liubimova LS, Parovichnikova EN, Mendeleeva LP, Mamotiuk KS, Demidova IA, Gribanova EO, Gal'tseva IV, Pokrovskaia OS, Kuz'mina LA, Zhelnova EI, Kliasova GA, Glasko EN, Kaplanskaia IB, Poreshina LP, et al. Transplantations of allogenic and autologous hemopoietic stem cells in acute leukemia (results of 20-year experience). Terapevticheskiy arkhiv. 2007;79 (7):30-35. (In Russian).

4. Afanasyev BV, Zubarovskaya LS, Moiseev IS. Allogeneic hematopoietic stem cell transplantation in children: now, problems and prospects. Russian Journal of Children Hematology and Oncology. 2015;2(2):28-42. (In Russian).

5. Rudakova TA, Kulagin AD, Klimova OU, et al. Severe "poor graft function" after allogeneic hematopoietic stem cell transplantation in adult patients: incidence, risk Factors, and outcomes. Clinical Oncohematology. 2019;12(3):309-318 (In Russian).

6. Olsson R, Remberger M, Schaffer M, Berggren DM, Svahn BM, Mattsson J, Ringden O. Graft failure in the modern era of allogeneic hematopoietic SCT. Bone Marrow Transplant. 2013;48: 537-543.

7. Alchalby H, Yunus DR, Zabelina T, Ayuk F, Kröger N. Incidence and risk factors of poor graft function after allogeneic stem cell transplantation for myelofibrosis. Bone Marrow Transplant. 2016;51(9):1223-1227.

8. Stasia A, Ghiso A, Galaverna F, Raiola AM, Gualandi F, Luchetti S, Pozzi S, Varaldo R, Lamparelli T, Bregante S, Van Lint MT, diGrazia C, Bacigalupo A. CD34+ selected cells for the treatment of poor graft function after allogeneic stem cell transplantation. Biol Blood Marrow Transplant. 2014;20:1440-1443.

9. Gale RP. Early and late graft-failure after transplants. Bone Marrow Transplant. 2016;51:182-183.

10. Valcárcel D, Sureda A. Graft failure. The EBMT Handbook (2019). doi.org/10.1007/978-3-030-02278-5_41.

11. Solar GP, Kerr WG, Zeigler FC, Hess D, Donahue Ch, de Sauvage FJ, Eaton DL. Role of c-mpl in Early Hematopoiesis. Blood. 1998; 92(1):4-10.
12. Ninos JM, Jefferies LC, Cogle ChR, Kerr WG. The thrombopoietin receptor, c-Mpl, is a selective surface marker for human hematopoietic stem cells. J Transl Med. 2006;4:9. doi: 10.1186/1479-5876-4-9.

13. Bussel JB, Cheng G, Saleh MN, Psaila B, Kovaleva L, Meddeb B, Kloczko J, Hassani H, Mayer B, Stone NL, Arning $M$, Provan D, Jenkins JM. Eltrombopag for the treatment of chronic idiopathic thrombocytopenic purpura. N Engl J Med. 2007; 29;357(22):2237-2247

14. Cheng G, Saleh MN, Marcher C, Vasey S, Mayer B, Aivado M, Arning M, Stone NL, Bussel JB. Eltrombopag for management of chronic immune thrombocytopenia (RAISE): a 6-month, randomised, phase 3 study. Lancet. 2011; 29; 377(9763):393-402.

15. Winkler T, Fan X, Cooper J, Desmond R, Young DJ, Townsley DM. Eltrombopag for refractory severe aplastic anemia: dosing, duration, long term outcomes and clonal evolution. Blood, 2019:

16. Ecsedi M, Lengline É, Knol-Bout C, Bosman P, Eikema DJ, Afanasyev B, Maschan A, Dreger P, Halkes CJM, Drexler B, Cortelezzi A, Drénou B, Patriarca A, Bruno B, Onofrillo D, Lanino E, Pulanic D, Serventi-Seiwerth R, Garnier A, Ljungman P, Bonifazi F, Giammarco S, Tournilhac O, Pioltelli P, Rovó A, Risitano AM, de Latour RP, Dufour C, Passweg J. Use of eltrombopag in aplastic anemia in Europe. Ann Hematol. 2019; 98(6):1341-1350.

17. Mittelman M, Platzbecker U, Afanasyev B, Grosicki S, Wong RSM, Anagnostopoulos A, Brenner B, Denzlinger C, Rossi G, Nagler A, Garcia-Delgado R, Portella MSO, Zhu Z, Selleslag D. Eltrombopag for advanced myelodysplastic syndromes or acute myeloid leukaemia and severe thrombocytopenia (ASPIRE): a randomised, placebo-controlled, phase 2 trial. Lancet Haematol. 2018;5(1):e34-e43. DOI: 10.1016/ S2352-3026(17)30228-4.

18. Oliva EN, Alati C, Santini V, Poloni A, Molteni A, Niscola P, Salvi F, Sanpaolo G, Balleari E, Germing U, Fenaux P, Stamatoullas A, Palumbo GA, Salutari P, Impera S et al. Eltrombopag versus placebo for low-risk myelodysplastic syndromes with thrombocytopenia (EQoL-MDS): phase 1 results of a single-blind, randomised, controlled, phase 2 superiority trial. Lancet Haematol. 2017;4:e127-e136. DOI: 10.1016/S2352-3026(17)30012-1.

19. Kong Y, Wang YT, Hu Y, Han W, Chang YJ, Zhang XH, Jiang ZF, Huang XJ. The bone marrow microenvironment is similarly impaired in allogeneic hematopoietic stem cell transplantation patients with early and late poor graft function. Bone Marrow Transplant. 2016;51:249-255.

20. Rondón G, Saliba RM, Khouri I, Giralt S, Chan K, Jabbour E, McMannis J, Champlin R, Shpall E. Long-term follow up of patients who experienced graft failure post allogeneic progenitor cell transplantation. Results of a single institution analysis. Biol Blood Marrow Transplant. 2008; 14(8): 859-866.

21. Kröger N, Holler E, Kobbe G, Bornhäuser M, Schwerdtfeger R, Baurmann H, Nagler A, Bethge W, Stelljes M, Uharek L, Wandt H, Burchert A, Corradini P, Schubert J, 
Kaufmann M, Dreger P, Wulf GG, Einsele H, Zabelina T, Kvasnicka HM, Thiele J, Brand R, Zander AR, Niederwieser $\mathrm{D}$, de Witte TM. Allogeneic stem cell transplantation after reduced-intensity conditioning in patients with myelofibrosis: a prospective, multicenter study of the Chronic Leukemia Working Party of the European Group for Blood and Marrow Transplantation Blood. 2009;114(26):5264-5270.

22. Dominietto A, Raiola AM, van Lint MT, Lamparelli T, Gualandi F, Berisso G, Bregante S, Frassoni F, Casarino L, Verdiani $S$ and Bacigalupo A. Factors influencing haematological recovery after allogeneic haemopoietic stem cell transplants: graft-versus-host disease, donor type, cytomegalovirus infections and cell dose. $\mathrm{Br} \mathrm{J}$ Haematol. 2001;112:219-227.

23. Yu J-M, Emmons RV, Hanazono Y, Sellers S, Young NS, Dunbar CE. Expression of interferon- $\gamma$ by stromal cells inhibits murine long-term repopulating hematopoietic stem cell activity. Exp Hematol. 1999;27(5):895-903.

24. Kong Y, Wang Yu-Tong, Cao Xie-Na, Song Yang, Chen Yu-Hong, Sun Yu-Qian, Wang Yu, Zhang Xiao-Hui , Xu Lan-Ping, Huang Xiao-Jun. Aberrant T cell responses in the bone marrow microenvironment of patients with poor graft function after allogeneic hematopoietic stem cell transplantation. J Transl Med. 2017;15:57. doi: 10.1186/s12967-017$1159-\mathrm{y}$.

25. Rudakova TA, Eismont YuA, Moiseev IS, Zubarovskaya LS, Kulagin AD, Afanasyev BV. Role of polyomavirus in emerging secondary hypofunction of marrow graft following allogeneic bone marrow transplantation in adults. Cellular Therapy and Transplantation. 2016;5(3):79-82. DOI: $10.18620 / \mathrm{ctt}-1866-8836-2016-5-3-79-82$.

26. Bao W, Bussel JB, Heck S, He W, Karpoff M, Boulad N, Yazdanbakhsh K. Improved regulatory T-cell activity in patients with chronic immune thrombocytopenia treated with thrombopoietic agents. Blood. 2010;116:4639-4645.

27. Alvarado LJ, Andreoni A, Huntsman HD, Cheng $\mathrm{H}$, Knutson JR, Larochelle A. Heterodimerization of TPO and IFN $\gamma$ impairs human hematopoietic stem/progenitor cell signaling and survival in chronic inflammation. Blood. 2017;130:4.

28. Lisukov IA, Uspenskaya OS, Kulagin AD, Bondarenko SN, Rudakova TA, Slesarchuk O.A., Afanasyev BV. Romiplostim in thrombocytopenia treatment after allogeneic bone marrow transplantation. Oncohematology. 2012;7(1):29-34. (In Russian).

29. Marotta S, Marano L, Ricci P, Cacace F, Frieri C, Simeone L, Trastulli F, Vitiello S, Cardano F, Pane F, Risitano AM. Eltrombopag for post-transplant cytopenias due to poor graft function. Bone Marrow Transplant. 2019;54(8):1346-1353.

30. Tang C, Chen F, Kong D, Ma Q, Dai H, Yin J, Li Zh, Chen Ji, Zhu X, Mao X, Wu D, Tang X. Successful treatment of secondary poor graft function post allogeneic hematopoietic stem cell transplantation with Eltrombopag. J Hematol Oncol. 2018 ;11:103 https://doi.org/10.1186/s13045-018-0649-6.

31. Liga M. Romiplostim for the treatment of thrombocytopenia after allogeneic stem cell transplantation. The 45th
Annual Meeting of EBMT (Physicians, Poster Session). Bone Marrow Transplantation. 2019;54:144-619, P143.

32. Aguirre L. Eltrombopag (EPAG) induces a high percentage of responses in patients with post allo-HSCT poor graft function (PGF) and no active GVHD. The 45th Annual Meeting of EBMT (Physicians, Poster Session). Bone Marrow Transplantation. 2019;54:144-619, P133. 


\section{Агонисты рецептора тромбопоэтина для лечения гипофункции трансплантата после аллогенной трансплантации гемопоэтических стволовых клеток у взрослых}

Татьяна А. Рудакова, Александр Д. Кулагин, Иван С. Моисеев, Татьяна А. Быкова, Сергей Н. Бондаренко, Мария В. Барабанщикова, Анастасия В. Бейнарович, Анна А. Осипова, Варвара Н. Овечкина, Александр Л. Алянский, Елена И. Дарская, Елена В. Морозова, Борис В. Афанасьев

НИИ детской онкологии, гематологии и трансплантологии им. Р. М. Горбачевой Первого Санкт-Петербургского государственного медицинского университета им. И. П. Павлова, Санкт-Петербург, Россия

\section{Резюме}

Посттрансплантационные цитопении в структуре гипофункции трансплантата являются жизнеугрожающим осложнением аллогенной трансплантации гемопоэтических стволовых клеток (алло-ТГСК). Общепринятые терапевтические опции для лечения ограничены повторными инфузиями гемопоэтических стволовых клеток. Однако миметики тромбопоэтина (ТПО), показавшие свою эффективность при идиопатической апластической анемией и тромбоцитопении (ромиплостим, элтромбопаг), могут рассматриваться в качестве возможной альтернативной стратегии терапии гипофункции трансплантата после алло-ТГСК. В данной работе представлен опыт использования агонистов рецептора тромбопоэтина для лечения посттрансплантационных цитопений, в том числе критериальной тяжелой гипофункции трансплантата после алло-ТГСК в нашем центре.

В общей сложности 31 пациент (15 мужчин, 16 женщин) со средним возрастом 22 года (18-57) получили терапию агонистами рецептора ТПО (АР-ТПО) для посттрансплантационной тромбоцитопении $<20 \times 10^{9}$ /л $(\mathrm{n}=7)$ и ГФТ $(\mathrm{n}=24)$. Для терапии использовался ромиплостим $(\mathrm{n}=17)$ со средней дозой 5 мкг/кг в неделю (3-5) или элтромбопаг $(\mathrm{n}=14)$ со средней дозой 50 мг/день (50-150). Критериями тяжелой гипофункции трансплантата (тГФТ) были: цитопения в двух или более миелоидных линиях (тромбоциты $<20 \times 10^{9} / л$, абсолютное число нейтрофилов (АЧН) $<0,5 \times 10^{9}$ /л, гемоглобин $<70$ г/л в любое время после документированного приживления, полный или стабильный смешанный донорский химеризм $>90 \%$ без признаков рецидива основного заболевания. Общий ответ включал полный ответ (ПО) (тромбоциты $\geq 100 \times 10^{9} /$ л, АЧН $\geq 1,5 \times 10^{9} /$ л, гемоглобин $\geq 100$ г/л) и частичный ответ (ЧО) (тромбоциты $>20 \times 10^{9}$ /л, АЧН $\geq 0,5 \times 10^{9}$ /л, гемоглобин $>70$ г/л). Медиана времени от постановки диагноза тГФТ до начала терапии АР-ТПО составила 14 дней (0-119), медиана продолжительности терапии АР-ТПО составила 3 недели (1-43). Переносимость АР-ТПО была удовлетворительной, без признаков токсичности II-IV степени. В общей сложности в 8 случаях (28\%) АР-ТПО использовались в комбинации с ритуксимабом $(\mathrm{n}=4)$, ритуксимабом и инфузиями донорских лимфоцитов (ИДЛ) $(\mathrm{n}=3)$, а также с инфузиями CD34-клеток $(\mathrm{n}=1)$. Всего 14 (48\%) пациентов достигли ответа (ПО: $\mathrm{n}=4,14 \%$; ЧО: $\mathrm{n}=10$, $34 \%)$. Комбинированная терапия не показала преимущества в скорости ответа по сравнению с АРТПО в монорежиме. Медиана прироста АЧН у ответивших на терапию составила $3,4 \times 10^{9} /$ л $(0,8-6,0)$, тромбоцитов - $48 \times 10^{9} /$ л (21-205). В общей сложности 15 пациентов (3 ответивших, 12 не ответивших на терапию) умерли от инфекции $(\mathrm{n}=10)$, рецидива $(\mathrm{n}=2)$ и острой реакции «трансплантат-против-хозяина» (оРТПX) III-IV степени $(\mathrm{n}=3)$. Однолетняя общая выживаемость (OB) от начала терапии составила 60\% (95\% ДИ, 40-76), при этом наблюдалась существенная разница между ответившими и неответившими на АР-ТПО: 79\% (95\% ДИ, 47-93) против 39\% (95\% ДИ, 14-63) ( $\mathrm{p=0,01).} \mathrm{Наше} \mathrm{исследование}$ показало многообещающую эффективность и удовлетворительную безопасность АР-ТПО у пациентов с тГФТ после алло-ТГСК. Необходимо проведение многоцентровых проспективных исследований для установления оптимальной дозы и продолжительности приема, а также критериев отмены этих препаратов.

\section{Ключевые слова}

Алло-ТГСК, гипофункция трансплантата, агонисты рецепторов тромбопоэтина. 